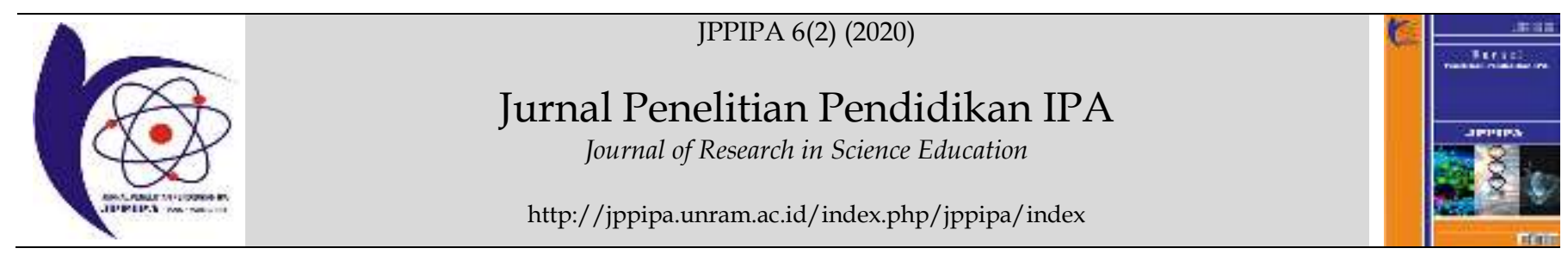

\title{
The Effect of Based E-learning Contextual Approach on Student Learning Motivation
}

\author{
Ilyas $^{1 *}$, An Nisaa Al Mu'min Liu ${ }^{1}$ \\ ${ }^{1}$ Physics Education Program, Flores University, East Nusa Tenggara, Indonesia
}

\section{DOI: $\underline{10.29303 / \text { jppipa.v6i2.425 }}$}

\section{Article Info}

Received : April 20th 2020

Revised : June 19th, 2020

Accepted: June 29th, 2020

\begin{abstract}
One of the fundamental problems for students is the low motivation to learn. The reason is the learning approach used by lecturers in the classroom is less attractive. Therefore this study about the use of contextual approaches based on e-learning to help student motivation. This quantitative study uses descriptive statistical analysis and inferential statistics to describe the data of students' motivation in the Physics Education Study Program at the University of Flores on simple harmonic wave material using a contextual approach based on e-learning. The data collection technique used is a non-test technique. The results of the descriptive analysis showed that the average motivation of students was 78.90 in the sufficient category. Inferential statistics results show a t-value of 5,453 and sig (2-tailed) of 0.000 less than 0.05 . So, it was concluded that the contextual approach based on e-learning (Zoom Cloud Meeting) influenced the motivation of students.
\end{abstract}

Keywords: Contextual Approach; E-learning; Learning Motivation.

Citation: $\quad$ Ilyas., Liu, A.N.A.M. (2020). The Effect of Based E-learning Contextual Approach on Student Learning Motivation. Jurnal Penelitian Pendidikan IPA (JPPIPA), 6(2), xx-xx. doi: https:/ / doi.org/10.29303/jppipa.v6i2.425

\section{Introduction}

The progress of a nation is determined by the quality of human resources as a driver of national life (Sole, 2017). The quality of human resources is closely related to the progress of education. The quality of education is strongly influenced by the ability of teachers, the availability of adequate tools and facilities, the ability of students, support from schools, the choice of approaches and methods in learning (Farida, et al., 2014; Pramudyawan, et al., 2020). These factors will be interrelated. The implementation of learning in schools is a factor that influences the quality of schools (Muzakar, 2014). The learning approach used needs attention from various parties (Gani, 2015). Learning strategies used in schools will be directly related to success in achieving student learning goals. Learning is categorized as successful if students have mastered the material in a cognitive, psychomotor, and affective manner (Siswadi, 2018).

Learning approaches that are not appropriate to the state of the school will have an impact on the achievement of learning objectives and the success of students understanding the concepts learned (Juleha, et al., 2014; Doyan A, et al., 2018; Supriadi, et al., 2020). In addition to the learning approach that can affect motivation in student learning, another thing that influences is the completeness of tools and facilities. An example is the existence of information technology. Along with the rapid development of information technology (IT), the need for IT-based concepts and learning mechanisms becomes inevitable. This development in the last decade has given rise to wireless information communication technology 
systems that are integrated directly with global network-based information processing devices so that the dimensions of space and time no longer limit with anyone to interact with each other. This development has offered a new pattern in learning, including in tertiary institutions, namely e-learning. E-learning has become one of the very basic needs of the academic community, especially in the learning process that does not allow for face-to-face meetings in the classroom. As in the present that requires online learning. Given that both lecturers, students, and educational institutions have used computer technology in teaching and learning activities. This study aims specifically to determine the effect of e-learning based contextual approaches on student learning motivation. This research is very important to do to help find solutions to improve education, especially in the University of Flores Physics Education Program.

This research is related to research that has been done before, with the title of the research is to increase understanding of the concept of waves using the Contextual Teaching and Learning (CTL) model in coastal schools. Problems raised in learning are contextual problems. The results of research that have been done show that learning using the CTL learning model is effective in improving several learning outcomes such as cognitive abilities and scientific attitudes, and can motivate students in teaching and learning activities (Ilyas, 2019).

Contextual learning is learning that helps teachers connect material taught with students' realworld situations and encourages students to make connections between the knowledge they have and apply it in their daily lives. The seven main components of contextual learning, namely: constructivism, inquiry, questions and answers, learning communities, modeling, reflection, and authentic assessment (Komalasari, 2015). The CTL approach in teaching and learning activities in class actively engages students, and lecturers as facilitators by connecting teaching materials with real-life contexts in optimizing individuals and groups according to the conditions needed (Nurlela, 2016). A contextual approach is a conception that helps teachers connect material concepts with real-world situations and motivate students to make connections between the knowledge they have and their application in life as family members and the community. The learning process in class takes place naturally in the form of activities that students do and experience themselves, not the transfer of knowledge from teacher to student. From the above opinions, it can be concluded that CTL is a learning system that helps teachers connect the material taught with students' real-world situations and encourage students to make connections between the knowledge they have and their daily lives.

The contextual approach can be used not only in conventional classes but also through e-learning. A teacher is required to plan innovative and creative learning using technology-based learning (Kristiawan, 2014). One of them is by zoom cloud meeting. Elearning via zoom cloud meeting is learning that is compiled using an electronic system or also a computer so that it can support the teaching and learning process (Allen, 2013). E-learning is a learning system used in the learning process without face-to-face between teacher and students (Ardiansyah, 2013).

E-learning will bring a new atmosphere in a variety of learning development. Utilization of elearning properly can increase learning motivation to the maximum. Some of the benefits of e-learning are shortening learning time and cost savings; e-learning as a facility of interaction between students and material; sharing information and subject matter can be accessed at any time; with e-learning, the process of developing knowledge does not only occur in the classroom, but students can be actively involved in the teachinglearning process (Rohmah, 2016). Thus the application of e-learning in higher education is expected to provide increased student interaction with each other and with lecturers, and the availability of unlimited learning resources. E-learning that is properly developed is effective in increasing the quality of graduates and the quality of higher education. The formation of a learning community that interacts with one another in giving and receiving and is not limited to one location can improve the motivation and quality of lecturers because it is possible to explore more extensive and even unlimited information and increase student motivation.

The contextual approach based on e-learning is expected to affect student motivation. High motivation is expected to facilitate achieving maximum learning outcomes. There are various definitions of motivation to learn by experts. For example, Petri (1981) as quoted by Cetin (2015) revealed that learning motivation is a nurturer or guide of students' innate behavior and strengths. As a concept, learning motivation is defined as an internal factor with four components, namely the opportunity to achieve success, concerns about failure, interests, and challenges. Motivation can be classified into two parts, namely intrinsic motivation and extrinsic motivation. Intrinsic motivation is motivation that is found in individual students. Extrinsic motivation is external reinforcement outside the individual self. This refers to extrinsic motivation which is very dependent on goals outside the individual or student (Hanurawan, 2016). McCoach \&

Siegle (2003), in Garn \& Jolly (2014) said that learning motivation is one of the factors that can 
distinguish students who maximize their learning potential from students who lack academic achievement. Aside from being one of the factors that determine the direction of attitude, willingness, and perseverance in learning (Keller, 2016), learning motivation also refers to expectations and values, where expectations show that students can complete assignments and show student confidence to succeed in learning (Riconscente, 2014). Wigfield \& Guthrie (2013) states that beliefs, values, and goals to be achieved in the learning process, the choice of activities to be learned, and perseverance in learning activities are included in the indicators of student motivation. According to Reeve (2016), to see student motivation in learning, what must be seen is the latent behavior of students, the intensity of students in learning, the direction of attitude while studying, and the persistence to learn. Based on the explanation of the learning motivation indicators above, it can be concluded that various indicators can be used to measure student motivation. Students who have learning motivation tend to pay attention to the duration of learning activities, frequency of activities, perseverance, fortitude, tenacity, and ability to face obstacles and difficulties, dedication and sacrifice, level of aspiration, level of achievement, and direction of learning attitude. Students who have high learning motivation tend to be involved in all learning activities intensively, focused, and diligently during the learning process. Learning motivation is a strength within students that encourages them to be willing and diligent in learning, make the best and directed efforts in the learning process to achieve the best results which are the goals that are owned and maintained throughout the learning process.

\section{Method}

This type of research is quantitative descriptive. The instrument used in this study was a non-test instrument. Non-test techniques in the form of questionnaires to see student motivation. The population from of this study were all students of physics education study program semester IV study year 2018/2019. Samples were taken using random sampling. This research independent variable is the use of contextual approaches basic e-learning and the control variable is learning motivation. The design of this study is one shot case study.

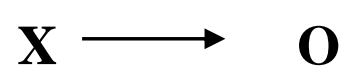

$X:$ Treatment

$\mathrm{O}:$ Observation
The data obtained will be analyzed quantitatively, using descriptive analysis and inferential analysis of SPSS software assistance. Descriptive statistical analysis with the help of SPSS 21.0 is descriptive statistics to see the minimum and maximum values as well as the mean and standard deviation of learning motivation. Inferential Analysis for test the prerequisite of analysis and hypothesis testing.

The analysis prerequisite test used is the normality test intended to find out whether the research data comes from populations that are normally distributed or not. Normality testing is performed using SPSS version 21.0 software using Kolmogorov Smirnov. The basis for decision making is if significant (sig)> 0.05 , then the data is normally distributed.

In this study using one sample $t$ test. The test was carried out with the help of SPSS software version 21.0, namely using one-sample $t$ test. The basis for decision making is that if significant (sig. 2-tailed) $<0.05$ then $\mathrm{H}_{0}$ is rejected and $\mathrm{H}_{1}$ is accepted.

\section{Result and Discussion}

The data described in this study are learning motivation data obtained from questionnaire motivation to study of 25 items. Description of student learning motivation data is as presented in Table 1 below.

Table 1: Description Of Student Learning Motivation

\begin{tabular}{llll}
\hline Variable & Information & Statistic & Std. Error \\
\hline Motivation & Mean & 78.9048 & 1.63285 \\
& Minimum & 67.00 & \\
& Maximum & 91.00 & \\
& Std. Deviation & 7.48268 & \\
\hline
\end{tabular}

From table 1, can we see a minimum score of 67.00 and a maximum score of 91.00 from an ideal score of 100 with an average of 78.90. If categorized are included in the enough category.

Before testing the hypothesis, first the basic analysis of the test is a normality test. The results of the normality test analysis are obtained through the data processing output from SPSS 21.0 for windows, as shown in table 2:

Table 2: Tests Of Normality

\begin{tabular}{llll}
\hline \multirow{2}{*}{ Variable } & \multicolumn{3}{c}{ Shapiro-Wilk } \\
\cline { 2 - 4 } & Statistic & df & Sig. \\
\hline Learning outcomes & 0.929 & 21 & 0.132 \\
\hline
\end{tabular}

From table 2 above shows the results of the normality test using the SPSS program which illustrates 
that the data on learning motivation scores of students are normally distributed. This can be seen from the significance value which indicates the value of 0.132 which is certainly greater than 0.05 , so it can be said that the data is normally distributed. Normally distributed data continued with hypothesis testing.

Hypothesis testing aims to answer the research hypothesis. The results of the requirements test indicate that all data from the population are normally distributed. So hypothesis testing with one sample $t$ test can be done. The results of data analysis with one sample $t$ test in this study were obtained from SPSS output 21.0 for windows. The results are as presented in table 3 below:

Table 3: One Sample t Test

\begin{tabular}{llll}
\hline Variabel & $\mathrm{t}$ & $\mathrm{df}$ & Sig. (2-tailed) \\
\hline Motivation & 5.453 & 20 & 0.000 \\
\hline
\end{tabular}

From table 3 it can be seen that the sig (2-tailed) value for the learning motivation variable is obtained 0,000 which is certainly smaller than 0.05 , it can be said that $\mathrm{H}_{0}$ is rejected and $\mathrm{H}_{1}$ is accepted, meaning that the contextual approach basec on e-learning influences the learning motivation of students physics education study programs.

The contextual approach based on e-learning can influence student learning motivation because the main factor in CTL learning is students learn through investigating and discovering so they can learn with enthusiasm and fun. Students learn from what they do every day. The teacher acts as a facilitator, to increase students' insights so that the material is easily understood. The CTL system helps students discover the meaning of what they are learning through adjusting material to an event in their daily lives; personal, social, and cultural life (Fadhilah, et al., 2016). CTL allows students to connect teaching material with daily events to achieve learning goals (Susialita, 2016). This means that CTL provides motivates for students to organize and direct their learning and to link their knowledge and application with every event that occurs in their lives.

A Contextual learning system is a learning system that is based on the philosophy that students learn when they know the meaning in academic material and then connect the new information they get with previous knowledge. There are three things contained in CTL learning so that it can influence student motivation in learning, namely (Firdaus, 2016): First, contextual learning emphasizes student-centered learning in finding material and meaning, the learning process is oriented directly to students. The learning process in CTL does not expect students to receive subject matter, but they seek and find their knowledge. Second, CTL encourages students to find links between the material learned and real-life situations, thus students are expected to understand the relationship between learning experiences and real life. This is very important, by connecting material found in real life, the material will be very meaningful and embedded in students' minds, so it is not easily forgotten. Third, CTL learning emphasizes students to apply it in real life. CTL not only expects students to do it, but understands the material they are learning. The CTL approach is one of innovative learning with educational patterns or methods from teaching to learning and from teachercentered to student-centered (Bustani \& Corebima, 2017; Karim et al., 2018). According to Kohoiron \& Sutadji (2016), CTL is a learning system that helps educators associate subject matter with real situations and encourages students to regulate scientific approaches and apply them in everyday life.

\section{Conclusion}

Based on the results of research that has been done as for the conclusion of this research is the contextual approach based on e-learning has an effect on student learning motivation in Physics Education Programs Flores University

\section{Acknowledgements}

Researcher would like to thank YAPERTIF and LPPM Flores University for facilitating the implementation of this research.

\section{References}

Ardiansyah, I. (2013). Eksplorasi Pola Komunikasi dalam Diskusi Menggunakan Moddle pada Perkuliahan Simulasi Pembelajaran Kimia, Universitas Pendidikan Indonesia, Bandung-Indonesia.

Bustami, Y., \& Corebima, A.D. (2017). The Effect of JiRQA Learning Strategy on Critical Thinking Skills of Multiethnic Students in Higher Education, Indonesia. International Journal of Humanities Social Sciences and Education (IJHSSE), 4(3), 13-22. Retrieved from https:// www.arcjournals.org/pdfs/ijhsse/v4i3/3.pdf

Allen, M. (2013). Michael Allen's Guide to E-learning. Canada : John Wiley \& Sons.

Cetin, B. (2015). Academic Motivation and SelfRegulated Learning in Predicting Academic Achievement in College. Journal of International Education Research, 11(2), 96-106. doi: https://doi.org/10.19030/jier.v11i2.9190

Doyan, A., Taufik, M., \& Anjani, R. (2018). Pengaruh Pendekatan Multi Representasi terhadap Hasil 
Belajar Fisika Ditinjau dari Motivasi Belajar Peserta Didik. Jurnal Penelitian Pendidikan IPA, 4(1), 35-45.doi: https://doi.org.10.29303/ippipa.v4i1.99

Fadhilah, Effendi, Z.M., \& Ridwan. (2017). Analysis of contextual teaching and learning (CTL) in the course of applied physics at the mining engineering department. International Journal of Science and Applied Science: Conference Series, 1(1), 25-32.doi:

https://doi.org.10.20961/ijsascs.v1i1.5106

Farida, C. A., Murniati, \& Khairuddin. (2014). Supervisi Pengajaran Oleh Kepala Sekolah untuk Meningkatkan Kinerja Guru di SMP Negeri 12 Banda Aceh. Jurnal Administrasi Pendidikan, 4(2), 133-156. Retrieved from http://www.jurnal.unsyiah.ac.id/JAP/article/vie $\underline{w} / 2517 / 2364$

Firdaus, \& Dewi, F. 2018. Application of Contextual Teaching and Learning (CTL) Components In Telecommunication Network Design and Optimization Course. International Journal of Chemistry Education Research (IJCER), 2(1), 24-33. doi: https://doi.org/10.20885/ijcer.vol2.iss1.art5

Gani, A. (2015). Pengaruh Model Pembelajaran dan Persepsi Tentang Matematika Terhadap Minat dan Hasil Belajar Matematika Siswa SMP Negeri Di Kecamatan Salomekko Kabupaten Bone. Jurnal Daya Matematis, 3(3), 337-343. Retrieved from https://ojs.unm.ac.id/JDM/article/view/1700/7 $\underline{36}$

Garn, A. C., \& Jolly, J. L. (2014). High Ability Students Voice on Learning Motivation. Journal of Advanced Academics, 25 (1), 7-24. doi: https:/ / doi.org/10.1177/1932202X13513262

Hanurawan, F. (2016). Perspektif alternatif dalam psikologi pendidikan (1 ${ }^{\text {st }}$ Ed.). Malang: Universitas Negeri Malang.

Ilyas., \& Liu, A. A. 2019. The Development of physic learning Tools Based on Contextual Teaching and Learning in a Remote Island Area. Jurnal Pendidikan Fisika Universitas Muhammadiyah Makassar. 7(1): 1-8. Retrieved from https://journal.unismuh.ac.id/index.php/ipf/art icle/view/1590/1369

Juleha, S., Khuzaemah, E., \& Cahyani, D. (2014). Penerapan Strategi Belajar Murder untuk Meningkatkan Penguasaan Konsep Siswa pada Pembelajaran Biologi Kelas VIII MTs Al-Ikhlas Setupatok Cirebon. Science Educatia, 3(2), 95-109. Retrieved from http://www.syekhnurjati.ac.id/jurnal/index.php /sceducatia/article/view/543

Karim, A. A., Khalid, F., Nasir, M. K. M., Maat, S. M., Daud, M. Y., \& Surat, S. (2018). Enablers to Information Search and Use in Higher Learning.
Creative Education, 9(14), 2089-20100. doi: https://doi.org/10.15294/jpii.v7i4.11721

Keller, J. M. (2016). Motivation, Learning, and Technology: Applying the ARCS-V Motivation Model. Participatory Educational Research, 3 (2), 113. Retrieved from http://www.perjournal.com/archieve/issue_3_2 L1-per_16 06_volume_3_issue_2_page_1_15.pdf

Khoiron, A. M., \& Sutadji, E. (2016). Kontribusi Implementasi Pendidikan Karakter dan Lingkungan Sekolah terhadap Berpikir Kreatif serta Dampaknya pada Kompetensi Kejuruan. Jurnal Pendidikan dan Pembelajaran (JPP), 22(2), 103-116. Retrieved from http://journal.um.ac.id/index.php/pendidikandan-pembelajaran/article/view/7731

Komalasari. (2015). Pembelajaran Kontekstual Konsep dan Aplikasi. Bandung: PT. REFIKA ADITAMA.

Kristiawan, M. (2014). A Model for Upgrading Teachers Competence on Operating Computer as Assistant of Instruction. Global Journal of Human- Social Science Research, 14(5). Retrieved from https:// www.researchgate.net/publication/3160 93866_A_Model_for_Upgrading_Teachers'_Comp etence_on_Operating_Computer_as_Assistant_of Instruction

Muzakar. (2014). Kinerja Kepala Sekolah dalam Meningkatkan Mutu Lulusan pada Madrasah Tsanawiyah Negeri Meureubo. Jurnal Ilmiah Islam Futura, 4(1), 110-133. Retrieved from https://jurnal.ar-

raniry.ac.id/index.php/islamfutura/article/view $\angle 83$

Nurlela, E.S.I., Sujana, A., \& Isrok'atun. (2016). Penerapan Pendekatan Contextual Teaching And Learning Untuk Meningkatkan Hasil Belajar Siswa Pada Materi Energi Panas.Pena Ilmiah, 1(1), 501-510. Retrieved from https://ejournal.upi.edu/index.php/penailmiah Larticle/view/2979

Pramudyawan, M. T. S., Doyan, A., \& Ardhuha, J. (2020). Pengaruh Model Pembelajaran Inkuiri Terbimbing Berbantuan Kit Alat Percobaan Usaha dan Energi terhadap Penguasaan Konsep Fisika Peserta didik. Jurnal Penelitian Pendidikan IPA, 6(1), 40-44. doi: http:// doi.org/10.29303/jppipa.v6i1.290

Reeve, J. (2016). A Grand Theory of Motivation: Why Not? Springer.

Riconscente, M. M. (2014). Effects of Perceived Teacher Practices on Latino High School Student Interest, Self-Efficacy, and Achievement in Mathematics. The Journal of Experimental Education, 50-74. doi: https://doi.org/10.1080/00220973.2013.813358

Rohmah, L., (2016). Konsep E-Learning Dan 
Aplikasinya Pada Lembaga Pendidikan Islam. An-

Nur, 3(2). Retrieved from

http://jurnalannur.stiq.ac.id/index.php/An-

Nur/article/view/9/0

Siswadi, Susilawati, \& Hikmawati. (2018). Pengaruh Pendekatan VAK (Visualizati pada, Auditory, Kinestetik) terhadap Hasil Belajar Fisika Peserta Didik SMPN 10 Mataram. Jurnal Penelitian Pendidikan IPA. Vol. 4 (1): 30-34. doi: http://doi.org/10.29303/jppipa.v4i1.100

Sole, F. B., \& Anggraeni, D. M. (2017). Pengembangan Instrumen Penilaian Sikap Ilmiah Sains Siswa Sekolah Dasar (SD) Berbasis Pendidikan karakter. Jurnal Penelitian Pendidikan IPA, 3(2), 99-105. doi: http://doi.org/10.29303/jppipa.v3i2.111

Susialita, T. (2016). The Development of Audio-visual Student Portfolios (LKS) Contextual Teaching and Learning-based (CTL) on Sound Chapter of Science Subject for Deaf Students. Jurnal Pendidikan IPA Indonesia, 5(2), 192-198. doi: https://doi.org/10.15294/jpii.v5i2.6734

Supriadi., Wildan., \& Laksmiwati, D. (2020). Implementasi Model Pembelajaran Berbasis Masalah dan Pengaruhnya terhadap Perkembangan Karakter Mahasiswa. Jurnal Penelitian Pendidikan IPA, 6(1), 63-68. doi: http://doi.org/10.29303 / jppipa.v6i1.323

Wigfield, A., \& Guthrie, J. T. (2013). Educational Psychologist: Motivation For Reading:Individual, Home, Textual, and Classroom Perspectives. Spring, 57-58. Retrieved from http://www.cori.umd.edu/researchpublications/1997-wigfield-guthrie 